\title{
O Capital Monopolista-Financeiro e a Grande Recessão
}

\author{
FOSTER J. B.; MAGDOFF, F. The Great Financial Crisis: Causes \\ and Consequences. New York: Monthly Review Press, 2009.
}

\author{
Alex Wilhans Antonio Palludeto \\ Rogerio P. de Andrade
}

A análise econômica marxista é marcada pela existência de abordagens reconhecidamente distintas. Há controvérsias recorrentes acerca do significado de quase todo o legado de Marx e de sua adequação para a compreensão dos fenômenos econômicos modernos. As inúmeras interpretações sobre a crise recente que o tomam como principal referência ilustram a pluralidade e a vitalidade que caracterizam a economia política marxista.

Embora não exista na obra de Marx de forma bem articulada e sistematizada uma teoria geral da crise capitalista, este tema é objeto recorrente de análise na economia política marxista. Não é surpresa, portanto, que a última grande crise do capitalismo, conhecida como "Grande Recessão", seja área de estudos de uma ampla gama de teóricos marxistas contemporâneos, como, por exemplo, David Harvey, Andrew Kliman, Gerard Duménil, John Foster e Fred Magdoff, para citar alguns.

Um aspecto central das teorias das crises capitalistas de inspiração marxista é que as crises são o resultado da operação das contradições inerentes ao modo de produção capitalista.

- Doutorando Universidade Estadual de Campinas - Instituto de Economia (IE-UNICAMP) Endereço: Rua Pitágoras, 353 - Barão Geraldo, Campinas - São Paulo/SP - Brasil CEP: 13083-857 - E-mail: alex.wilhans@gmail.com

- Professor Universidade Estadual de Campinas - Instituto de Economia (IE-UNICAMP) Endereço: Rua Pitágoras, 353 - Barão Geraldo, Campinas - São Paulo/SP - Brasil CEP: 13083-857 - E-mail: roger.andrade@uol.com Recebido em 01 de maio de 2014. Aceito em 04 de junho de 2014. 
Elas não se originam de eventos que ocorrem fora do sistema econômico, mas emergem em virtude do seu próprio desenvolvimento. A questão que então se coloca é: quais são essas contradições? A identificação daquela que se crê central na explicação da crise é o que separa as várias abordagens marxistas sobre o tema. Neste sentido, na literatura econômica marxista existem três vertentes mais gerais que procuram explicar a natureza das crises: a teoria do subconsumo (por ex., Rosa de Luxemburgo, Paul Sweezy), a das desproporções interdepartamentais (Rudolf Hilferding) e a baseada na lei da tendência à queda da taxa de lucros (Paul Mattick, David Yaffe).

A tradição teórica inaugurada pela publicação, em 1966, do consagrado livro Capital Monopolista, de autoria de Paul Baran e Paul Sweezy, representa, hoje, uma dessas correntes. Veiculada, sobretudo, pela revista Monthly Review, a qual Sweezy ajudou a fundar, em 1949, e na qual se manteve como editor até o seu falecimento, em 2004, esta abordagem, também conhecida como "Escola do Capital Monopolista", tem sido desenvolvida e aplicada a um conjunto variado de fenômenos econômicos, entre os quais a crise recente.

A visão mais elaborada sobre o que seus autores chamam de Grande Crise Financeira, a partir dessa corrente interpretativa, encontra-se no livro The Great Financial Crisis, de John Bellamy Foster e Fred Magdoff, de 2009. ${ }^{1}$ Da introdução e dos seis capítulos que compõem o livro de Foster e Magdoff, apenas aquela e o último capítulo foram redigidos exclusivamente para o livro. Os demais, originalmente publicados na Monthly Review sob a forma de artigos entre 2006 e 2008, foram reproduzidos sem alterações.

Ainda que tributários da extensa literatura marxista que se desenvolve desde o final do século XIX, Foster e Magdoff (2009, p. 8) deixam clara sua inspiração nos trabalhos de Baran, Sweezy e Harry Magdoff, autores que, por sua vez, apoiaram-se fortemente em T. Veblen, J. A. Schumpeter, J. M. Keynes, M. Kalecki, J. Steindl e H. Minsky - além, evidentemente, de Marx.

1 Mais recentemente, esta vertente marxista passou a considerar, no tratamento da crise, um conjunto mais amplo de países no livro The Endless Crisis, de 2012, do mesmo J. B. Foster e de Robert McChesney. Além dos Estados Unidos, Foster e McChesney (2012) dedicam-se à Europa, ao Japão e àquilo que os autores denominam "Global South" - com particular ênfase na China. Foster e McChesney (2012) procuram analisar a relação entre a estagnação/financeirização das economias maduras, o impacto da crise recente que nelas se verificou, entre as quais a crise europeia, e o processo de sobreacumulação no Global South. 
Com efeito, a tentativa de examinar as causas e as consequências da Grande Recessão proposta por Foster e Magdoff (2009) pode ser concebida como uma extensão, para a atual conjuntura, de duas obras associadas à abordagem da qual fazem parte: por um lado, conforme já indicado acima, a interpretação proposta por Baran e Sweezy em Capital Monopolista; por outro, o conjunto de ensaios acerca da economia mundial de Magdoff e Sweezy (1987) reunidos no livro Stagnation and Financial Explosion.

O fio condutor da análise de Foster e Magdoff (2009) é a tese de que o capitalismo que emerge a partir da segunda metade do século XIX, marcado por grandes empresas organizadas tipicamente sob a forma de sociedade por ações, apresenta uma tendência permanente à estagnação. Nas palavras dos autores: "Stagnation, of course, does not mean that there is no growth whatsoever. Rather, the economy functions well below its potential - with appreciable unused productive capacity and significant unemployment and underemployment." (Foster e Magdoff, 2009, p. 39)

Por um lado, tem-se o crescente potencial produtivo da sociedade, possibilitado pelo próprio movimento de concentração e centralização do capital e o desenvolvimento tecnológico que a ele se associa processos que se encontram na origem do surgimento e consolidação das grandes empresas. Por outro, níveis de consumo e investimento insuficientes para absorver o crescente excedente econômico ${ }^{2}$ gerado por essa forma de organização da produção. A estagnação, portanto, é concebida como o estado normal de uma economia na qual há uma tendência ao crescimento do excedente (Baran e Sweezy, 1966, cap. 3) e, simultaneamente, uma capacidade limitada para absorvê-lo sobretudo pela ausência de oportunidades rentáveis de investimento (Foster e Magdoff, 2009, p. 39).

2 O excedente econômico (economic surplus) é definido por Baran e Sweezy (1966, p. 112) como "the difference between total social output and the socially necessary costs of producing it". A sugestão do uso desta categoria, em substituição à mais-valia (surplus value) de Marx, levou diversos autores, também reconhecidos no meio acadêmico marxista, a questionar sua validade teórica: "The substitution has been made because Baran and Sweezy have switched from Marxian to bourgeois economic analysis, which does not operate with class terms such as value and surplus-value but with the amalgam national income, the concept of 'effective demand', and the Keynesian remedies for capital stagnation. It would indeed be a strange kind of 'Marxism' which paid more attention to the distribution of surplus-value among the capitalists and their retainers than to the division of the social product between labour and capital." (Mattick, 1978, p. 191) 
Baixo crescimento econômico agregado, crescente excesso de capacidade produtiva e altos níveis de desemprego/subemprego convertem-se, assim, nos traços fundamentais do capitalismo monopolista.

Dessa forma, momentos de prosperidade, como aqueles do imediato pós-Segunda Guerra, período tradicionalmente conhecido como a Era de Ouro do capitalismo, são exceções e devem ser compreendidos a partir dos meios pelos quais o excedente foi absorvido (ou realizado). De acordo com Foster e Magdoff (2009), em uma argumentação que reproduz, quase que ipsis litteris, Baran e Sweezy (1966), a tendência à estagnação é - e o foi historicamente - acompanhada por uma série de contra-tendências, capazes de conferir dinamismo temporário à economia ao servirem de escoadouro ao excedente não absorvido. ${ }^{3}$ Entre as principais, destacam-se, por um lado, a combinação do desenvolvimento de novas tecnologias, produtos e a elevação do dispêndio em esforço de vendas (marketing, por exemplo); e, por outro, o crescimento dos gastos do governo nas diversas esferas da administração pública e, sobretudo, na área militar. No entanto, ainda que possam permitir períodos de relativo vigor econômico, esses fatores são limitados:

[...] growth of civilian government spending was strictly limited by the fact that it tended to intrude on areas of private accumulation. Military spending needed to be justified in terms of some external threat, and hence could only go so far. The sales effort was only rational at the level of the firm insofar as it translated into additional sales and increased market share. [...] While the stagnation ten-

3 O foco na insuficiência crônica de demanda e, sobretudo, na necessidade de estímulos externos ao processo de valorização do capital para que o crescimento econômico seja possível fez com que a abordagem da Escola do Capital Monopolista fosse considerada uma nova versão da já conhecida tese do subconsumo - criticada com veemência por muitos marxistas desde o final do século XIX. Segundo Shaikh (1978, p. 220), "[the underconsumptionists argue that] the capitalist system is incapable of self-expansion. It must grow to survive, but it requires some external source of demand (like the non-capitalist world) in order to keep it growing. This means that its reproduction is ultimately regulated by factors outside of the system: the limits to the system are external to it". Por essa razão, tomando como referência a lei da queda tendencial da taxa de lucro, Shaikh (1991, p. 161) argumenta que, ao invés de uma teoria da necessidade da crise capitalista, os subconsumistas/estagnacionistas defendem uma teoria da possibilidade, na qual a crise ocorre se e quando se verifica uma particular combinação de fatores históricos. Para maiores detalhes, ver Shaikh (1991) e para uma defesa da Escola do Capital Monopolista às diversas críticas que, graças ao seu reconhecido viés subconsumista, ao longo do tempo lhe foram dirigidas, ver Foster (1986). 
dency was deeply rooted, powerful and persistent, the countervailing tendencies were more superficial, weaker and self-limiting. (Foster e Magdoff, 2009, pp. 65-66)

O capitalismo contemporâneo caracteriza-se, todavia, segundo os autores, por uma nova e poderosa forma de absorção do excedente - apenas sugerida en passant por Baran e Sweezy (1966), mas desenvolvida com profundidade por Magdoff e Sweezy (1987): as finanças. ${ }^{4}$ De acordo com Foster e Magdoff (2009), este processo de "autonomia das finanças em relação à produção" desenrola-se da seguinte forma:

Unable to find profitable outlets for their investment-seeking surplus within the productive economy, corporations/capitalists sought to augment their money capital by means of financial speculation, while the financial system in its turn responded to this increased demand for its "products" with a bewildering array of new financial instruments - including stock futures, options, derivatives, hedge funds, etc. The result was the rise by the 1980s of a financial superstructure that increasingly took on a life of its own. (Foster e Magdoff, 2009, p. 72)

$\mathrm{O}$ redirecionamento do excedente para as atividades financeiras e o maior peso relativo que estas adquiriram nas últimas décadas correspondem ao processo que os autores denominam de financeirização: a mudança do centro de gravidade da economia da produção para as finanças, traço distintivo do sistema capitalista moderno (Foster e Magdoff, 2009, p. 18). Tamanha é a importância atribuída ao fenômeno, que são levados a sugerir que o capitalismo mundial entrou, a partir de então, em uma nova fase de seu desenvolvimento, marcada pela combinação de estagnação e financeirização.

\footnotetext{
4 "Far from failing to even 'hint' at the role of finance, Monopoly Capital had included at the very end of the chapter on 'The Sales Effort' a separate section on the role of the finance sector as an outlet for surplus absorption, arguing that this was 'on an equal footing with the sales effort'" (Foster e Magdoff, 2009, pp. 68-69).
} 
Segundo os autores, o capitalismo monopolista cedeu lugar, nas últimas décadas, ao capitalismo monopolista-financeiro. (Foster e Magdoff, 2009, cap. 3)

Embora estejam cientes de que a rápida expansão do crédito, fruto do acelerado desenvolvimento das atividades financeiras, foi um dos mais importantes fatores que contrabalançaram a tendência à estagnação no período recente, sobretudo pelo consumo, como contrapartida ao baixo crescimento dos salários reais, Foster e Magdoff (2009) constatam que boa parte desses recursos voltou-se para a própria esfera financeira:

[B] allooning of finance produced new outlets for surplus in the finance, insurances, and real estate (FIRE) sector of GDP in the form of new investment in buildings, office, equipment, etc. Nevertheless, the great bulk of the money capital devoted to finance was used for speculation in securities, real estate, and commodities markets rather than for investment in capital goods, and thus did not feed into the growth of GDP, which continued to stagnate. (Foster e Magdoff, 2009, p. 67)

Nesse sentido, três principais aspectos acabaram por definir a etapa do capital monopolista-financeiro:

(1) The stagnation of the underlying economy meant that capitalists were increasingly dependent on the growth of finance to preserve and enlarge their money capital. (2) The financial superstructure of the capitalist economy could not expand entirely independently of its base in the underlying productive economy - hence the bursting of speculative bubbles was a recurrent and growing problem. (3) Financialization, no matter how far it extended, could never overcome stagnation within production. (Foster e Magdoff, 2009, p. 83) 
A relativa autonomização das atividades financeiras, ainda que funcional como meio de absorção do excedente, representou, portanto, uma fonte de instabilidade adicional a um capitalismo cuja esfera produtiva já se encontrava debilitada. As sucessivas bolhas que marcaram a história recente dos Estados Unidos são, desse modo, manifestações necessárias da tensão permanente entre a estagnação produtiva e a explosão financeira.

A crise recente, cujo estopim foi o colapso da bolha do mercado imobiliário norte-americano, é, de acordo com os autores, resultado da dinâmica inerente a essa fase, fruto da estagnação latente e da instabilidade gerada pelo setor financeiro - cujo crescimento acelerado se deve à própria estagnação. $\mathrm{O}$ descompasso entre o inexpressivo crescimento da renda agregada, em particular dos salários reais, ${ }^{5}$ e a proliferação de ativos financeiros diversos encontrou na crise, na incapacidade da economia real validar as crescentes demandas da esfera financeira, sua expressão máxima. Por conseguinte, concluem os autores, "both the financial explosion in recent decades and the financial implosion now taking place are to be explained mainly in reference to stagnation tendencies within the underlying economy." (Foster e Magdoff, 2009, p. 120)

Resolver definitivamente os problemas gerados pela atual etapa do capital monopolista-financeiro significa, conforme sugerem os autores, superar o próprio capitalismo enquanto forma de organização da produção, algo que, como não poderia deixar de ser vindo de autores marxistas, inscreve-se na esfera da ação política:

it is necessary for the population to seize control of their political economy, replacing the present system of capitalism with something amounting to a real political and economic democracy; what the present rulers of the world fear and decry most - as "socialism." (Foster e Magdoff, 2009, pp. 139-140)

5 "A key element in explaining this whole dynamic is to be found in the falling ratio of wages and salaries as a percentage of national income in the United States." (Foster e Magdoff, 2009, p. 129) 


\section{Referências}

BARAN, P.; SWEEZY, P. Monopoly Capital. New York: Monthly Review Press, 1966.

FOSTER, J. B. The Theory of Monopoly Capitalism. New York: Monthly Review Press, 1986.

FOSTER J. B.; MAGDOFF, F. The Great Financial Crisis: Causes and Consequences. New York: Monthly Review Press, 2009.

FOSTER, J. B.; McCHESNEY, R. W. The Endless Crisis. New York: Monthly Review Press, 2012.

MAGDOFF, H.; P. SWEEZY, P. Stagnation and Financial Explosion. New York: Monthly Review Press, 1987.

MATTICK, P. Anti-Bolshevik Communism. London: Merlin, 1978.

SHAIKH, A. "An Introduction to the History of Crisis Theories". In: Union for Radical Political Economics - URPE. U.S. Capitalism in Crisis. New York: Monthly Review Press, 1978.

SHAIKH, A. "Economic Crises”. In: BOTTOMORE, T. (ed.) A Dictionary of Marxist Thought. Oxford: Blackwell, 1991. 